UDC 658.8:339.187

JEL Classification: G 00, E 49, E 59

http://doi.org/10.21272/mmi.2019.2-18

Enikő Korcsmáros,

Ph.D., J. Selye University, Slovakia

Renáta Machová,

Ph.D., Associate Professor, J. Selye University, Slovakia

Zoltán Šeben,

PhD., J. Selye University, Slovakia

Lilla Feher,

J. Selye University, Slovakia

\title{
CHANGING IN CONSUMER LOYALTY AS A REACTION FOR EU INTEGRATION IN SLOVAKIA
}

Abstract. It has been 10 years since the introduction of the euro in Slovakia. Regarding the introduction of the single currency, we can highlight factors that have contributed to the economic recovery experienced in recent years. Besides the positive effects, the negative effect appeared as well. The basic goal of the research is to map the experience Slovakia had with the introduction of the euro, 10 years following the introduction of the single currency. In order to achieve the research objectives, we applied primary data collection to obtain information about the researched issue. An anonymous questionnaire survey was conducted among the respondents. Data collection among the residents was realized with the help of an agent, but also an online questionnaire was provided for the respondents in the time interval of 6-20th December 2018. Basic statistic indicators were used to verify our assumptions. The most informed about the role of the ECB and the EU common financial policy were the respondents of age group 26-40, while the respondents over 56 were more informed where the ECB is headquartered. These results can be explained by the fact that the younger generation developed resistance towards the political situation in the EU, they have less interest and show indifference. The proportion of respondents with a clear negative opinion has increased both among the respondents with full secondary school degree and those with college or university degree. The biggest disadvantage they experienced was the increasing price of products. We find it important to suggest that the active involvement of MEPs within a framework of an intensive information campaign is essential. The main objective would be to bring closer the EU economic policy to economically active people and make them less resistant and uninterested in the policy of the EU due to lack of information. We recommend highlighting positive facts regarding the introduction of the single currency not only in the field of international trade but also in everyday transactions on national and EU level. An information campaign is suggested to highlight the positive aspects. The original contribution and the main added value of the paper is the mapping of the consequence of the euro introduction in Slovakia. The example of Slovakia can be a starting point for the tasks to be completed by the neighbouring EU member countries e.g. Czech Republic, Hungary to enter the eurozone.

Keywords: consequence, EU integration, euro, primary research, Slovakia, ECB.

Introduction. Based on the decision of the European Council in June 1989, the first phase of the establishment of the European Economic and Monetary Union (EMU) started on 1 July 1990. The obstacles of capital movement between the member states have been removed and harmonization of the monetary policy between the member states started to achieve price stability. The establishment of the European Monetary Institute (EMI) on 1 January 1991 marked the second phase of the establishment of the EMU. The European Monetary Institute (EMI) had two main objectives: strengthening the cooperation and harmonization of the monetary policy of the national central banks (NCBs); preparation tasks related to the establishment of European System of Central Banks (ESCB) in order to better coordinate the monetary policy and prepare the introduction of the single currency. The EMI was set up as a temporary body in the third phase of the preparation, but the coordination of monetary and exchange rate policy in the EU remained at the national level. The third phase of EMU

Cite as: Korcsmáros, E., Machová, R., Šeben, Z., \& Feher, L. (2019). Changing in Consumer Loyalty as a Reaction for EU Integration in Slovakia. Marketing and Management of Innovations, 2, 206-216. http://doi.org/10.21272/mmi.2019.2-18 

Slovakia

started on 1 January 1999 when the single currency was named euro. The main aim of the work is to map the experience Slovakia had with the introduction of the euro, 10 years following the introduction of the single currency.

Literature Review. The euro was officially introduced on 1 January 1999, when coordination of the common monetary policy of the EU was taken over by the European Central Bank (ECB). The first euro banknotes and coins were introduced on 1 January 2002, meanwhile, the circulation and use of the national currencies stopped. The euro coins and banknotes have become the legal tender in the member countries of the eurozone. (Soos, 2011, online). There was a smooth change to the use of euro banknotes and coins; neither the member states experienced the lack of banknotes nor the lack of coins. With the introduction of the euro, the last step of the monetary union was completed. Slovakia joined the monetary union of the EU on 1 January 2009 (Arato and Koller, 2015). The Maastricht convergence criteria are the criteria which the European Union member states are required to meet to enter the European Monetary Union. These criteria set that the inflation of the member state cannot be more than 1.5 percentage points above the rate of the three best performing member states. The government deficit cannot be more than $3 \%$, and the national debt cannot exceed $60 \%$ of the GDP. (Deltuvaite, 2017) It also requires the exchange rate stability; the participation in ERM II for at least two years without severe tensions. The long-term interest rate cannot be more than $2 \%$ percentage point above the three best performing member states in terms of price stability (Taksas, 2010, online). Slovakia signed an association agreement with the EU on 4 October 1993. The main goal of the Slovak government was to secure the political, economic and other conditions for joining the European Union. The first negotiations between Bratislava and Brussels took place in March 2000. The Accession Treaty was signed on 16 April 2003. Slovakia became a member state of the European Union on 1 May 2004 (Joining the EU, online). The country faced two other integration goals: accession to the Schengen area and the introduction of the single currency. In both cases, serious criteria had to be met. According to certain opinion, the smallest states of the Central and Eastern Europe had the greatest motivation to introduce a single currency. The economic policy of Slovakia focused to decrease the level of state redistribution, liberalization of the economy and the capital flow and tax reduction. (Stiblarova, 2015; Introduction of the euro in Slovakia - analytical report,2008, online). When Slovakia joined the European Union, the accession to the Economic and Monetary Union of the EU became a reality; a slight change in the economic policy of the country could be detected. The external and internal liberalization of the economy was a condition of the EU accession. The significant tax and expenditure cuts were linked to the turnaround of the economic policy in the first half of the 2000s. Slovakia, Slovenia and Estonia entered the strictly economic and financial requirements to introduce the single currency. The GDP of the mentioned three countries represented less than $1 \%$ of the total EU-27. The purchasing power of the whole community was just over $1 \%$. According to the surveys, the Slovak economy was regarded as an open economy in terms of foreign trade and trade in goods and services, closely linked to the euro area (Nemenyi and Oblath, 2012; Kocisova et al., 2018). Regarding the economic situation of the postcommunist countries that joined the EU, the introduction of the euro had more advantages than expected disadvantages. The following factors can be listed as advantages: the economic stability of the country might strengthen that results in capital influx; financing the private sector investment might fall. The further positive impact may be the decrease in inflation and the possibility to run high inflation might be avoided. The budget deficit might decrease, the public debt financing may become more efficient as well as transaction costs may fall (Taksas, 2010, online). Joining the European Monetary Union might also have disadvantages in economic and financial terms. This can be explained by the lack of autonomous monetary policy that results in erosion of the independent fiscal policy. Without the possibility of national currency devaluation, the competitiveness of the country joining the EU can worsen. In the case of asymmetric economic and financial shocks (e.g. Greece), the country might 

Slovakia

become heavily indebted. As the experience has shown, the introduction of the euro may result in shortterm inflation. There is a chance that a higher unemployment rate can stabilize than it was detected earlier. Due to the different economic cycle of the member countries, the economic policy of the EU can even be harmful to weaker performing member states (Taksas, 2010, online; Pappalardo and Vicarelli, 2017; Tkacova et al., 2017; Simionescu et al., 2017). Similarly, to other countries, the introduction of the euro was smooth in Slovakia as well. Regarding the introduction of the single currency, we can highlight three factors that have contributed to the economic recovery experienced in recent years. The first is the ability to attract foreign capital. The introduction of the euro resulted in an increased influx of working capital. The backbone of the Slovak economy was the increased number of foreign investments. The next factor is the establishment of a stable financial environment that results in the economic stability of the country. Countries waiting to join the EU have struggled with liquidity problems. Examining the condition of the Slovak economy, it appears that the mentioned problems disappeared and gained less importance with the introduction of the single currency and joining the EMU. (Slovakia joins the euro, 2009 , online). Besides the positive effects, the negative effect appeared as well. First of all, we have to mention the increase in prices in Slovakia compared to states out of the EMU area that resulted in a significant increase in wages spent beyond the country borders. As a further negative impact might be mentioned the transition costs. Slovakia experienced a further burden in form of international financial rescue packages as an extra cost for the country (Raczko, 2013, online). Despite the burdens and all the disadvantages of the euro introduction, Slovakia benefited from the introduction of the single currency. The development of the country and financial stability during the years of the economic crisis might be transparent for the post-communist countries, especially among the V4.

Methodology and research methods. The basic goal of the research is to map the experience Slovakia had with the introduction of the euro, 10 years following the introduction of the single currency. In order to achieve the research objectives, we applied primary data collection to obtain information about the researched issue. An anonymous questionnaire survey was conducted among the respondents. Data collection among the residents was realized with the help of an agent, but also an online questionnaire was provided for the respondents in the time interval of 6-20th December 2018. 219 completed questionnaires served as a basis for data collection. The questionnaire contained 23 questions, the vast majority of which were closed questions, but we used also open questions and Likert scale questions to assess the information in a detailed manner. The questions fall into the following groups:

a) questions focusing on the essential characteristics of the sample;

b) questions related to the introduction of the single currency and the common financial policy of the EU;

c) personal opinion and experience of the respondents related to the introduction of the single currency.

In order to analyse the collected data, we applied statistical methods, crosstab and distribution. By analysing primary data and bearing in mind the main goals of the research we have focused on the following assumptions:

Assumption 1: The 26-40 age group is the most informed about the introduction of the euro and the financial policy of the EU.

Assumption 2: Respondents with lower qualification have a rather negative attitude to single currency compared to those with higher qualification degree.

In addition to the formulated assumption, the analysis of data obtained via primary data collection is used to prove the following two hypotheses:

$\mathrm{H}$ 1: Those, over the age of 40 have a strong commitment to the Slovak Koruna, so the prices of products are often converted to the former currency of Slovakia. 
E. Korcsmáros, R. Machová, Z. Šeben, L. Feher. Changing in Consumer Loyalty as a Reaction for EU Integration in Slovakia

$\mathrm{H}$ 2: Respondents with higher qualification are more aware of the introduction of the euro in Slovakia.

A single-variable ANOVA and cross-table analysis were applied to analyse the hypotheses. The one-way analysis of variance (one-way ANOVA) is used to determine whether there are any statistically significant differences between the means of three or more independent groups, the expected values are compared, the null hypothesis to be tested will develop as the following:

$$
H_{0}: \mu_{1}=\mu_{2}=\mu M \ldots .=\mu
$$

ANOVA was applied to examine whether a non-metric independent variable has an effect on a metric dependent variable. If the independent variable has an impact on the dependent variable, the averages of the groups formed according to the values of the independent variable will differ. If the result of the ANOVA analysis is significant, the null hypothesis is rejected and the alternative hypothesis - the group averages differ - will be accepted (Takacs, 2016). Pearson's Chi-square Test expresses the statistical significance of the relationship between the two variables.

$$
\chi^{2}=\sum_{\text {total cells }} \frac{\left(f_{0}-f_{e}\right)^{2}}{f_{e}}
$$

The relationship is primarily based on the comparison of expected $\left(f_{e}\right)$ and observed $\left(f_{0}\right)$ values. To express the strength of the relationship, the Cramer $\mathrm{V}$ indicator was used, where $\mathrm{N}$ refers to the size of the sample and $k$ expresses the number of categories:

$$
V=\sqrt{\frac{\chi^{2}}{N(k-1)}}
$$

Results. A more detailed description based on the demographic features of the respondents is needed to introduce the survey results. $36.10 \%$ of the questionnaires focusing on primary data collection were filled by male and $63.90 \%$ by female respondents. We also put an emphasis on variety in terms of age groups and respondents with different qualification degree. Since the single currency was introduced ten years ago in Slovakia, the number of respondents under 18 and those with primary education represent the sample in a low number.

Table 1. Qualification and age distribution of survey respondents

\begin{tabular}{|c|c|c|c|c|}
\hline & Primary & Secondary vocational & Secondary & University \\
\hline Under 18 & $0,00 \%$ & $0,00 \%$ & $0,00 \%$ & $0,00 \%$ \\
\hline $\mathbf{1 8 - 2 5}$ & $0,00 \%$ & $0,00 \%$ & $41,10 \%$ & $19,63 \%$ \\
\hline $\mathbf{2 6 - 4 0}$ & $0,00 \%$ & $2,28 \%$ & $5,94 \%$ & $17,81 \%$ \\
\hline $\mathbf{4 1 - 5 5}$ & $0,00 \%$ & $0,46 \%$ & $4,11 \%$ & $5,94 \%$ \\
\hline $\mathbf{5 6 - 6 5}$ & $0,00 \%$ & $0,00 \%$ & $0,46 \%$ & $0,46 \%$ \\
\hline Over 65 & $0,46 \%$ & $0,00 \%$ & $1,37 \%$ & $0,00 \%$ \\
\hline
\end{tabular}

Source: developed by the authors based on primary data collection.

The qualification and age distribution of respondents also reflects one of the characteristic trends of the 21 st century Europe, regarding the general level of qualification. $42,5 \%$ of the respondents live in an urban area, while $57,7 \%$ come from rural areas. $46,1 \%$ of the respondents live in a relationship, $31,5 \%$ are single and $20,5 \%$ declared themselves married. The remaining number of respondents, $1,9 \%$ are 

Slovakia

either divorced or widowed. The distribution based on occupation and monthly income of the individuals indicates that it was possible to address respondents with different occupation and level of income in order to consider the opinion of a wider social layer about the introduction of the single currency.

Assumption 1: The 26-40 age group is the most informed about the introduction of the euro and the financial policy of the EU.

In order to justify our assumption, we approached the examined sample from different perspectives. We have examined all the answers related to the introduction of the single currency, the exchange rate of the euro and the Slovak koruna, the responsibility for the EU's common financial policy and the headquarter of the European Central Bank. A complex crosstab was constructed. Apart from the age distribution of those completing the questionnaire, we pointed to the ratio of those respondents, who remember when the single currency was introduced. We also examined, how much the respondents knew about the exchange rate of the euro and the Slovak koruna ( $1 €=30,216$ SKK). We were also interested in how familiar the respondents are with the role of the European Central Bank, the institution responsible for the common financial policy of the EU. Figure 1, presenting how informed the respondents are is based on a complex crosstab analysis. Because of the fact that respondents under 18 did not participate in the survey, this age group is not presented. The most informed about the exact time of the euro introduction was the age group of 56-65 and over $65(100 \%-100 \%)$; the least informed about this information was the age group $26-40$. Only $66,67 \%$ of the respondents provided a correct answer. The most informed about the euro and Slovak koruna exchange rate was again the age group of $56-65$ and over $65(100 \%-100 \%)$; the least informed were the representatives of age group 26-40 $(87,72 \%)$. The age group of $26-40$ could name the ECB, the institution responsible for the common financial policy. $84,21 \%$ of the respondents provided the correct answer for the question. The least informed about this fact were the representatives of the age group 56-65 and over 65 . Only $50 \%$ of the respondents provided the correct answer. The most informed about the headquarters of the ECB were the representatives of the age group 56-65 and over $65(50 \%-50 \%)$. The least informed about the fact that the ECB is headquartered in Frankfurt were the representatives of the age group 18-25 (20,30\%).

$18-25$

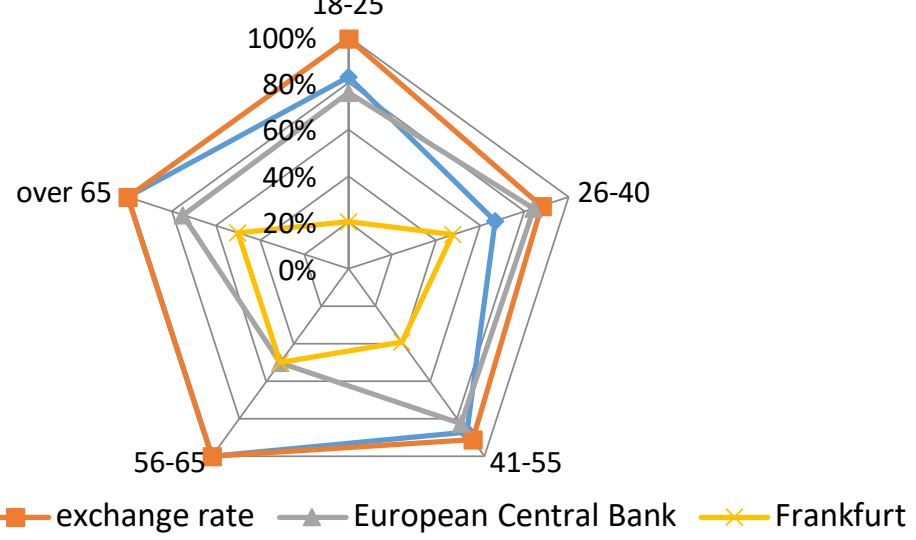

Figure 1. Respondents' level of awareness and knowledge about the introduction of the euro and the common financial policy of the EU based on age group distribution

Source: developed by the authors based on primary data collection.

Assumption 1 - The 26-40 age group is the most informed about the introduction of the euro and the financial policy of the EU - can be rejected. The age group of 26-40 could provide the name of the 
E. Korcsmáros, R. Machová, Z. Šeben, L. Feher. Changing in Consumer Loyalty as a Reaction for EU Integration in Slovakia

institution responsible for the common financial policy of the EU, but the age group of 56-65 and over 65 proved to be more informed in the rest of the details. This fact raises a number of questions, since the most informed respondents of age group over 56 are close to retirement age, while representatives of the younger generation are still active in the labour market. It would be necessary to inform them about the circumstances of the euro introduction and the institutional framework related to the single currency. In the following, we wanted to reveal the opinion of the respondents on the introduction of the single currency. Our assumption has been formulated on the basis of the poll conducted by the National Bank of Slovakia before the introduction of the euro.

Assumption 2: Respondents with lower qualification have a rather negative attitude to single currency compared to those with higher qualification degree.

Respondents interviewed during the research were divided into four groups based on their highest achieved qualification. The following groups were determined: respondents with primary education, respondents with secondary vocational education, respondents with a full secondary education degree and those with college or university degree. Primary degree as the highest level of education was achieved by 1 respondent (over 65 age group). The opinion of the representative of this age group is not relevant in terms of the survey conducted. Since we were looking for the opinion of respondents in different age groups, this data is also indicated in Table 2. Before the introduction of the euro $16,67 \%$ of those with secondary vocational education degree expressed rather a negative opinion about the single currency. $41,38 \%$ of the respondents with full secondary education degree expressed a more or less negative opinion about the euro, while $25 \%$ of those with university or college degree also expressed a negative opinion about the introduction of the single currency. Considering the fact that ten years have passed on after the introduction of the euro in Slovakia, the respondents were provided with an option to answer «l do not know». This option was chosen by those respondents who did not remember what their opinion was before the introduction of the euro or they did not feel the change to the new currency important. This option was chosen mainly by those with secondary vocational education degree (33, $33 \%$ ). Only $17,71 \%$ of the respondents with college or university degree chose this option; the vast majority of them $(82,29 \%)$ were able to express their opinion about the euro before the introduction of the single currency.

Table 2. Opinion of respondents on euro introduction in the past and present according to qualification degree

\begin{tabular}{|c|c|c|c|c|c|}
\hline & & Primary & $\begin{array}{l}\text { Secondary } \\
\text { vocation }\end{array}$ & Secondary & University \\
\hline \multirow{5}{*}{ 感 } & I was clearly a positive & $0,00 \%$ & $16,67 \%$ & $9,48 \%$ & $15,63 \%$ \\
\hline & I was rather a positive & $0,00 \%$ & $33,33 \%$ & $23,28 \%$ & $41,67 \%$ \\
\hline & I was rather a negative & $0,00 \%$ & $16,67 \%$ & $26,72 \%$ & $20,83 \%$ \\
\hline & I was clearly a negative & $100,00 \%$ & $0,00 \%$ & $14,66 \%$ & $4,17 \%$ \\
\hline & I do not know & $0,00 \%$ & $33,33 \%$ & $25,86 \%$ & $17,71 \%$ \\
\hline \multirow{5}{*}{ 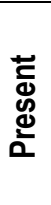 } & I am clearly a positive & $0,00 \%$ & $16,67 \%$ & $9,48 \%$ & $15,63 \%$ \\
\hline & I am rather a positive & $0,00 \%$ & $33,33 \%$ & $34,48 \%$ & $43,75 \%$ \\
\hline & I am rather a negative & $100,00 \%$ & $33,33 \%$ & $25,00 \%$ & $29,17 \%$ \\
\hline & I am clearly a negative & $0,00 \%$ & $16,67 \%$ & $25,86 \%$ & $9,38 \%$ \\
\hline & Other & $0,00 \%$ & $0,00 \%$ & $5,17 \%$ & $2,08 \%$ \\
\hline
\end{tabular}

Source: developed by the authors based on primary data collection.

We were also interested in how the introduction of the single currency in Slovakia is perceived by the respondents in the present. While $16,67 \%$ of those with secondary vocational degree expressed a 

Slovakia

negative opinion about the euro before the introduction of the single currency, the present survey results show that $33,33 \%$ of them still a negative opinion, but only $16,67 \%$ expressed a clearly negative opinion. The group of respondents with full secondary education degree has changed their opinion on the introduction of the single currency. The ratio of those with a positive opinion has increased from 23 , $28 \%$ to $34,48 \%$, and the ratio of those expressing a negative opinion have decreased from $26,72 \%$ to $25,00 \%$. More than 11 percent point increase was detected in the number of those respondents who developed a strong negative opinion about the introduction of the euro. Their ratio has increased from $14,66 \%$ to $25,86 \%$. A significant change in the opinion of respondents in the group of those with a college or university degree can be detected among those respondents who have rather a negative opinion about the introduction of the single currency. This ratio has increased from $20,83 \%$ to $29,17 \%$. The most surprising data is the number of those expressing a negative opinion. It has more than doubled from $4,17 \%$ to $9,38 \%$. It is clearly presented that regardless of qualification degree the opinion of respondents has changed. On the basis of the analysis, we cannot take a clear position since this would only be acceptable in case of the firm negative opinion of the respondents about the introduction of the single currency. Considering this fact, our assumption can be accepted with modifications: Those with secondary vocational and full secondary qualification are more likely to express a firm negative opinion about the single currency than those with college or university degree. The respondents were asked an open question about the main benefits and disadvantages of the introduction of the euro. $98,7 \%$ of the respondents answered that the main benefit of the introduction of the single currency made shopping and comparing prices easier in the countries introducing the euro. The research sample shows that 99 , $2 \%$ of the respondents find the price increase the biggest disadvantage. This can confirm the negative impact mentioned by Raczko (2013). Regardless of the fact, whether we asked the respondents about the negative or positive impacts of the euro introduction, everyday issues gained focus. The respondents had no interest to express their opinion on the national or EU level.

$\mathrm{H}$ 1: Those, over the age of 40 have a strong commitment to the Slovak Koruna, so the prices of products are often converted to the former currency of Slovakia.

In order to test our hypothesis, the $\mathrm{H}_{0}$ Hypothesis was formulated, as an alternative, we formulated the $\mathrm{H}_{1}$ hypothesis as well.

$\mathrm{H}_{0}$ : There is no significant correlation between the classification of respondents in age groups and whether the prices of products determined in euro are converted into the former Slovak currency.

$\mathrm{H}_{1}$ : There is a significant correlation between the classification of respondents in age groups and the conversion of product prices into the former Slovak currency.

The univariate ANOVA analysis was used to analyse our hypothesis, where the age of the respondents' figures as a dependent variable and whether the respondents convert the prices of products to the formerly used Slovak Koruna is determined as an independent variable. According to the null hypothesis of the Levene's test, the variances are not equal, so rejection of these results in the homogeneity of variances. The condition of the variance homogeneity is fulfilled (Table 3 ), the value stands at 0,877 that cannot be considered significant.

Table 3. Test of Homogeneity of Variances (Age)

\begin{tabular}{|r|r|r|r|}
\hline Levene Statistic & df1 & df2 & Sig. \\
\hline, 131 & 2 & 216 &, 877 \\
\hline
\end{tabular}

Source: developed by the authors through the SPSS software based on primary data collection.

The value of F-ratio in the ANOVA is 1, 927. Since the significance level of probability as a part of Ftest is $1,927>0,05$, the null hypothesis is accepted. According to $\mathrm{H}_{0}$, there is no significant correlation 
E. Korcsmáros, R. Machová, Z. Šeben, L. Feher. Changing in Consumer Loyalty as a Reaction for EU Integration in Slovakia

between the classification of respondents in age groups and whether the prices of products determined in euro are converted into the former Slovak currency.

Table 4. ANOVA Table (Age)

\begin{tabular}{|l|r|r|r|r|c|}
\hline & Sum of Squares & df & Mean Square & F & Sig. \\
\hline Between Groups & 2,799 & 2 & 1,399 & 1,927 &, 148 \\
\hline Within Groups & 156,854 & 216 &, 726 & & \\
\hline Total & 159,653 & 218 & & & \\
\hline
\end{tabular}

Source: developed by the authors through the SPSS software based on primary data collection.

Hypothesis 2: Respondents with higher qualification are more aware of the introduction of the euro in Slovakia.

To test our hypothesis, it is necessary to formulate hypothesis $\mathrm{H}_{0}$ and hypothesis $\mathrm{H}_{1}$.

$\mathrm{H}_{0}$ : There is no significant correlation between the qualification level of the respondents and their awareness of euro introduction in Slovakia.

$\mathrm{H}_{1}$ : There is a significant correlation between the qualification level of the respondents and their awareness of euro introduction in Slovakia.

Three questions formulated during our primary data collection aimed at investigation how well informed the respondents are about the introduction of the single currency. We were also interested in how informed the respondents were about the common financial policy of the EU, the headquarters of the ECB and the exchange rate of the euro and the Slovak Koruna.

Table 5. Chi-square Test - respondents' awareness about the introduction of the single currency in Slovakia

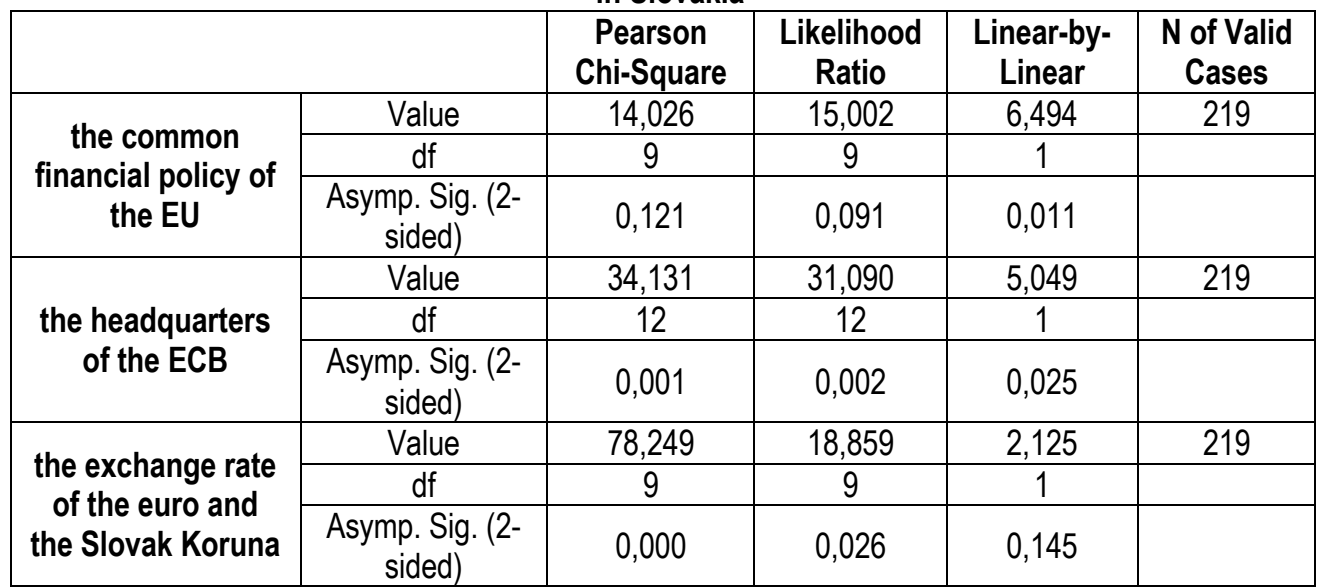

Source: developed by the authors through the SPSS software based on primary data collection.

The Chi-square Test result shows a significant correlation between the qualification level of the respondents and the awareness of respondents about the euro-koruna exchange rate and the location of the ECB. The significance level has not reached the value of 0,05 . We examined the Cramer $V$ values to determine the strength of association. 
E. Korcsmáros, R. Machová, Z. Šeben, L. Feher. Changing in Consumer Loyalty as a Reaction for EU Integration in Slovakia

Table 6. Values of Cramer $\mathrm{V}$ regarding the respondent awareness about the introduction of the single currency in Slovakia

\begin{tabular}{|c|c|c|}
\hline & Cramer V & Approx.Sig. \\
\hline the common financial policy of the EU & 0,146 & 0,121 \\
\hline the headquarters of the ECB & 0,228 & 0,001 \\
\hline the exchange rate of the euro and the Slovak Koruna & 0,345 & 0,000 \\
\hline
\end{tabular}

Source: developed by the authors through the SPSS software based on primary data collection.

In the case of the questions showing a significant correlation, we examined the strength of the association. Table 6results show a weak correlation between the qualification level of the respondents and the awareness of respondents about the euro-koruna exchange rate and the location of the ECB. According to the results of the statistical analysis, Hypothesis 2 can be accepted with the following modifications: Significant correlation can be detected between the qualification level of the respondents and the awareness of respondents about the euro-koruna exchange rate and the location of the ECB.

Conclusions. The development of the Slovak economy in the period of 2004-2008 was intense. The reform packages not only made the Slovak economy transparent but also made it attractive for foreign investors. Thanks to increased foreign investment in the country, the economy started to grow and record economic growth was recognized in the period of 2006-2007. Regional and social differences have not decreased as a result of economic growth. The introduction of the single currency in Slovakia resulted in short and long-term real economic costs and benefits. The introduction of the euro in Slovakia can be characterized as a smooth process. The empirical study conducted on the occasion of the 10th anniversary of the introduction of the euro in Slovakia was carried out among the residents of Slovakia with the help of a questionnaire survey. We were interested in how well informed the respondents of the survey were about the date of the euro introduction in Slovakia, the exchange rate between the single currency and the former currency of Slovakia, and the role of the European Central Bank. Surprising was the fact that the surveyed age group of 26-40 proved to be the least informed about the exact date of the euro introduction and the exchange rate of the euro and the Slovak koruna. In both cases, the respondents over 56 proved to be the most informed. The most informed about the role of the ECB and the EU common financial policy were the respondents of age group 26-40, while the respondents over 56 were more informed where the ECB is headquartered. These results can be explained by the fact that the younger generation developed resistance towards the political situation in the EU, they have less interest and show indifference. We find it important to suggest that active involvement of MEPs within a framework of an intensive information campaign is essential. The main objective would be to bring closer the EU economic policy to economically active people and make them less resistant and uninterested in the policy of the EU due to lack of information. We agree with the Nguyen et al. (2017) statement, that it is needed to make an effort to promote financial literacy by providing basic financial literacy of individuals at an earlier stage in the life cycle We have examined the opinion and behaviour of the respondents before the introduction of the single currency and 10 years after the introduction. It is remarkable how the perception of the respondents changed about the single currency they had before the introduction and 10 years after the introduction of it. The proportion of respondents with a clear negative opinion has increased both among the respondents with full secondary school degree and those with college or university degree. The biggest disadvantage they experienced was the increasing price of products. To avoid further increase of negative beliefs, we recommend highlighting positive facts regarding the introduction of the single currency not only in the field of international trade but also in everyday transactions on national and EU level. An information campaign is suggested to highlight the positive aspects. The example of Slovakia can be a starting point for the tasks to be completed by the neighbouring EU member countries e.g. Hungary to enter the eurozone. Slovakia joined the eurozone in 

Slovakia

the best possible period. It can provide shelter in the future and avoid extreme fluctuation of exchange rates and the risk of currency speculation.

Author Contributions: Authors have an equal contribution for preparing the manuscript. For the conceptualization E. K. and R. M., methodological issue by E. K. and R. M., analysis and investigation E. K., R. M., Z. S. and L. F. resources Z. S. and L. F., writing E. K. and R. M., revision Z. S. and L. F., formatting Z. S. and L. F.

Funding: «This research was funded by PALLAS ATHENE DOMUS FOUNDATION, grant number PADE-0117/4».

\section{References}

Arato, K., Koller, B. (2015) Europa utazasa, Integraciotortenet, Gondolat Kiado Budapest

Deltuvaite, V. (2017): Does Euro Introduction Ensure Lower Vulnerability of the New Euro Area Member to the External Stocks? The Case of the Central and Eastern European Countries. In. New Trends in Finance and Accounting - proceedings paper, pp. 17-27.

Introduction of the euro in Slovakia - analytical report (2008). Retrieved from http://ec.europa.eu/commfrontoffice/publicopinion/flash/fl_249_en.pdf. [Accessed 10 January 2019].

Findreng, J.H., (2014) Relative Purchasing Power Parity and the European Monetary Union: Evidence from Eastern Europe, Economics \& Sociology, 7(1), 22-38. DOI: 10.14254/2071-789X.2014/7-1/3

Joining the EU. Retrieved from: http://www.slovak-republic.org/eu/ [Accessed 04 January 2019].

Kocisova, K., Gavurova, B., \& Sopko, J. (2018). C Do more cards and terminals guarantee higher efficiency? The case of European Union banking. Journal of International Studies, 11(2), 49-62. doi:10.14254/2071-8330.2018/11-2/4

Nemenyi, J.-Oblath, G. (2012). Az euro hazai bevezetesenek újragondolasa. MTA Kozgazdasag es Regionalis Tudomany Kutatokozpont Kozgazdasag - tudomanyi Intezet 2012/14. Retrieved from: https://www.econstor.eu/bitstream/10419/108255/1/MTDP1214.pdf [Accessed 04 January 2019].

Nguyen, T.A.N., Rozsa, Z., Belas, J., Belasova, L. (2017). The effects of perceived and actual financial knowledge on regular personal savings: Case of Vietnam. Journal of International Studies, 10(2), pp. 278-291. doi:10.14254/2071-8330.2017/10-2/19

Pappalardo, C., Vicarelli, C. (2017). Euro introduction and the behaviour of Italian exporting firms. In. Oxford Economic Papers - new series, Vol. 69., Issue 4., pp.1054-1077.

Raczko, Zs. (2013) Az euro bevezetesenek gazdasagi hatasa Szlovakiara. Retrieved from: https://anzdoc.com/az-eurobevezetesenek-gazdasagi-hatasa-szlovakiara.html [Accessed 03 January 2019].

Simionescu, M., Lazanyi, K., Sopkova, G., Dobes, K., Balcerzak, A. P. (2017). Determinants of Economic Growth in V4 Countries and Romania. Journal of Competitiveness, Vol. 9, Issue 1, pp. 103-116. DOI: 10.7441/joc.2017.01.07

Slovakia joins the euro (2009). Retrieved from: http://ec.europa.eu/economy_finance/articles/euro/ article13563_en.htm. [Accessed 03 January 2019].

Soos, J. (2011). A monetaris integracio varhato hatasai Magyarorszagon. Retrieved from: https://szie.hu/file/tti/archivum/Soos_Janos_ertekezes.pdf [Accessed 03 January 2019].

Stiblarova, L. (2015). Financial Integration Process in the EU Countries after the Euro Introduction: Position of Slovakia. In. Central European Conference in Finance and Economics (CEFE2015) - proceedings paper. pp. 671-680.

Takacs, Sz. (2016). Bevezetes a matematikai statisztikaba, Antaresz Kiado, ISBN 978-6158-0544-09

Taksas, B. (2010). Az Europai Monetaris Uniohoz torteno csatlakozas potencialis elonyei es hatranyai Magyarorszag szempontjabol, Bolyai Szemle 2010/4. Retrieved from: http://archiv.uni-nke.hu/downloads/bsz/bszemle2010/4/07.pdf [Accessed 04 January 2019].

Tkacova, A., Gavurova, B., Behun, M. (2017). The Composite Leading Indicator for German Business Cycle. Journal of Competitiveness, Vol. 9, Issue 4, pp. 114-133. DOI: 10.7441/joc.2017.04.08

Еніко Корсмарос, Ph.D.. Університет ім. Яноша Сельє (Словаччина);

Рената Мачова, Ph.D.. доцент, Університет ім. Яноша Сельє (Словаччина);

Золтан Себен, Ph.D. Університет ім. Яноша Сельє (Словаччина);

Лілла Фехер, Університет ім. Яноша Сельє (Словаччина).

Зміна лояльності споживачів як реакція на Євроінтеграцію Словаччини

Вже десять років у Словаччині євро фрункціонує як єдина валюта. У статті авторами систематизовано фактори, які сприяли економічному зростанню після впровадження єдиної валюти (євро) в Словаччині. Авторами зазначено, що поряд із позитивними ефектами від 
E. Korcsmáros, R. Machová, Z. Šeben, L. Feher. Changing in Consumer Loyalty as a Reaction for EU Integration in Slovakia

впровадження єдиної валюти в Словаччині є й негативні наслідки. Головною метою дослідження є порівняння поведінки споживачів у Словаччині до впровадження євро як єдиної валюти та після десяти років. Для досягнення поставленої мети авторами здійснено первинний збір даних за допомогою анонімного опитування респондентів у період 6-20 грудня 2018 року. При цьому авторами використано основні статистичні методи для перевірки основних гіпотез. Таким чином за результатами дослідження встановлено, що найбільш поінформованими про роль Європейського центрального банку (ЄЦБ) та спільну фрінансову політику ЄС були респонденти вікової групи 26-40 років, тоді як респонденти старше 56 років були більш поінформовані про місцезнаходження головного офрісу ЄЦБ. Отримані результати дослідження пояснюються стійкістю молоді до політичної ситуації в ЄС, що відповідно зменшує ї̈ інтерес до політичних змін та реформ. Авторами зазначено, що питома вага респондентів з чітко негативною думкою про єдину валюту зросла як серед респондентів на базі повної середньої освіти, так і серед респондентів 3 профресійно-технічною або вищою освітою. При цьому зростання цін на продукцію стало найбільшим статистично значущим фактором, який негативно вплинув на споживачів. У статті наголошено, що активне залучення політиків Європарламенту в рамках інтенсивної інформаційної кампанії має важливе значення, що може позитивно вплинути на лояльність споживачів до євро як єдиної валюти. Так, це сформує передумови зростання поінфоормованості економічно активного суспільства про політику ЄС та підвищить рівень їх політичної свідомості. У свою чергу у статті визначено, що одним із позитивних наслідків економічної євроінтеграції $\epsilon$ поліпшення умов міжнародної торгівлі та щоденних фрінансово-економічних операцій як на національному рівні, так $і$ на рівні ЄС. Авторами запропоновано інформаційну кампанію для висвітлення позитивних аспектів економічної євроінтеграції Словаччини. Враховуючи отримані результати дослідження, авторами наголошено, що приклад Словаччини може стати відправною точкою для економічної євроінтеграції сусідніх країн-членів ЄС, таких як, Чехія чи Угорщина.

Ключові слова: наслідок, інтеграція ЄС, євро, первинне дослідження, Словаччина, ЄЦБ.

Manuscript received: 14.03.2019.

(C) The author(s) 2019. This article is published with open access at Sumy State University. 